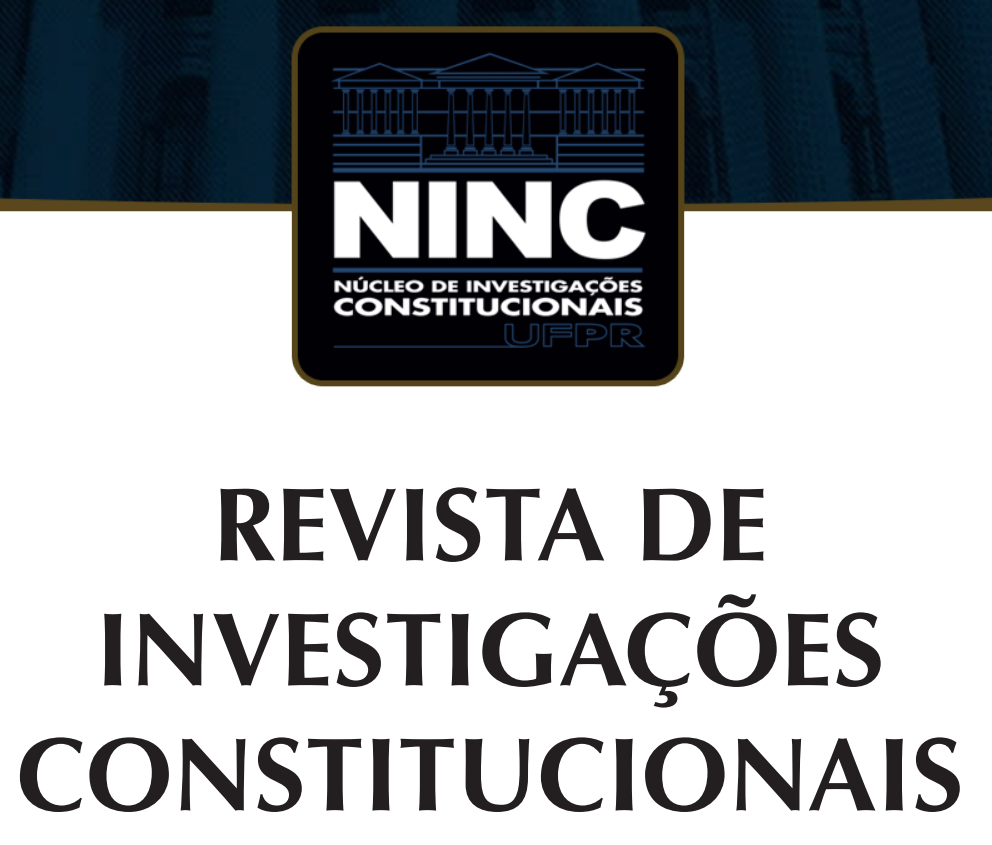

JOURNAL OF CONSTITUTIONAL RESEARCH

vol. 5 | n. 3 | setembro/dezembro 2018 | ISSN 2359-5639 | Periodicidade quadrimestral Curitiba | Núcleo de Investigações Constitucionais da UFPR | www.ninc.com.br 


\section{Constitucionalismo popular: modelos e críticas}

\section{Popular constitutionalism: models and criticism}

\section{JOSÉ RIBAS VIEIRA*}

Universidade Federal do Rio de Janeiro (Brasil) Pontifícia Universidade Católica do Rio de Janeiro (Brasil) jribas@puc-rio.br

\section{LILIAN MÁRCIA BALMANT EMERIQUE*}

Universidade Federal do Rio de Janeiro (Brasil) lilamarcia@gmail.com

\section{JÔNATAS HENRIQUES BARREIRA***}

Universidade Federal Fluminense (Brasil) jotahbarreira@hotmail.com

Recebido/Received: 27.09.2017 / September 27 $7^{\text {th }}, 2017$ Aprovado/Approved: 25.08.2018 / August 25 $5^{\text {th }}, 2018$

\section{Resumo}

O artigo aborda o constitucionalismo popular em seus principais autores. Em seguida, analisa os modelos apresentados para materializar este constitucionalismo popular. Depois disso, aponta os principais críticos desta corrente do pensamento constitucional americano. A

\section{Abstract}

The article brings up the popular constitutionalism, discussing its main authors. Following, it analyses the existing models idealized to materialize this popular constitutionalism. Then, the article points the main critics to this tendency of the American constitutional thought. Departing from

Como citar esse artigo/How to cite this article: VIEIRA, José Ribas; EMERIQUE, Lilian Márcia Balmant; BARREIRA, Jônatas Henriques. Constitucionalismo popular: modelos e críticas. Revista de Investigações Constitucionais, Curitiba, vol. 5, n. 3. p. 277-302, set./ dez. 2018. DOI: 10.5380/rinc.v5i3.55478.

* Professor Titular da Universidade Federal do Rio de Janeiro (Rio de Janeiro- RJ, Brasil). Professor Associado da Pontifícia Universidade Católica do Rio de Janeiro (Rio de Janeiro-RJ, Brasil). Pós-Doutor em Direito na Université Montpellier I (Montpellier, França). Doutor e Mestre em Direito pela Universidade Federal do Rio de Janeiro (Rio de Janeiro- RJ, Brasil). Mestre em Ciência Política pela Ohio University (Athens, Estados Unidos da América). Graduado em Direito, Educação e Ciências Sociais pela Universidade Federal do Rio de Janeiro. E-mail: jribas@puc-rio.br.

* Professora adjunta da Faculdade Nacional de Direito e do Programa de Pós-Graduação em Direito da Universidade Federal do Rio de Janeiro (Rio de Janeiro-RJ, Brasil). Pós-Doutora em Ciências Jurídico-Políticas pela Universidade de Lisboa (Lisboa, Portugal). Doutora em Direito pela Pontifícia Universidade Católica de São Paulo (São Paulo- SP, Brasil). Mestra em Direito pela Pontifícia Universidade Católica do Rio de Janeiro (Rio de Janeiro-RJ, Brasil). Mestra em Ciência Política e Relações Internacionais pela Universidade Nova de Lisboa (Lisboa, Portugal). E-mail: lilamarcia@gmail.com.

${ }^{* * * *}$ Mestre em Direito Constitucional pela Universidade Federal Fluminense (Rio de Janeiro-RJ, Brasil). Bacharel em Direito pela Pontifícia Universidade Católica de Campinas (Campinas - SP, Brasil). Advogado com inscrição na OAB/SP. Editor-Assistente da Revista Culturas Jurídicas. Bolsista CNPq/CAPES. E-mail: jotahbarreira@hotmail.com. 
partir de todas estas exposições, o artigo busca, através de uma revisão bibliográfica crítica das principais obras de referência do constitucionalismo popular, encontrar a possibilidade de uma visão conciliatória entre supremacia judicial e participação popular e identificar as principais contribuições do constitucionalismo popular.

Palavras-chave: constitucionalismo popular; constitucionalismo americano; revisão judicial; supremacia judicial; democracia. all these expositions, the article aims, through a critical bibliographic review of the best contributions of the popular constitutionalism, to find a possibility of reconciliation between judicial supremacy and popular engagement and identify the best contributions made by the popular constitutionalism.

Keywords: popular constitutionalism; American constitutionalism; judicial review; judicial supremacy; democracy.

\section{SUMÁRIO}

1. Introdução; 2. Panorama geral da questão do judicial review nos Estados Unidos; 3. O Constitucionalismo Popular; 3.1. Eleição para ministros da Suprema Corte; 3.2. O Constitucionalismo Popular Mediado de Barry Friedman; 4. As críticas ao Constitucionalismo Popular; 5. Considerações finais; 6 . Referências.

\section{INTRODUÇÃO}

"Nós não somos finais, porque somos infalíveis, mas nós somos infalíveis porque somos finais" (We are not final because we are infallible, but we are infallible only because we are final). Com estas palavras, o ministro Robert Jackson, no caso Brown v. Allen', descreveu não apenas a posição da Suprema Corte dos Estados Unidos, mas de muitas Supremas Cortes e Tribunais Constitucionais pelo mundo afora.

A revisão judicial sempre trouxe, nos Estados Unidos, uma grande preocupação quanto à legitimidade democrática dos tribunais para verificar os resultados obtidos pelo processo político. Esta polêmica se torna ainda maior quando se confere não apenas o poder ao Judiciário para invalidar leis que conflitam com a Constituição, mas também lhe concede a função de intérprete supremo, de instituição com o poder de dar a palavra final sobre o significado constitucional.

O presente artigo pretende analisar o regresso deste debate na academia norte -americana, ocorrida no começo deste século, através da corrente denominada Constitucionalismo popular.

A escolha por um marco teórico e um problema de pesquisa norte-americano é útil em virtude da natureza de relativa universalidade do constitucionalismo norte-americano, já que este é uma referência global no direito constitucional, sobretudo, em razão da supremacia da Constituição, com o marco do caso Marbury v. Madison. Assim, a discussão estadunidense possui grande importância para o próprio constitucionalismo

\footnotetext{
${ }^{1}$ UNITED STATES OF AMERICA. Supreme Court of United States. Brown v. Allen. 344 U.S. 443 (1953), tradução nossa. Disponível em: <https://supreme.justia.com/cases/federal/us/344/443/case.html>. Acesso em 29 de julho de 2017.
} 
brasileiro, que também é marcado por um modelo de supremacia da Constituição e revisão judicial.

Deste modo, a pesquisa visa, a partir de um método de revisão bibliográfica, visitar as principais obras do constitucionalismo popular, notadamente Larry Kramer, Mark Tushnet, Richard Parker e Jeremy Waldron; procurar a sugestão de modelos de constitucionalismo popular ou que aumentem a participação do povo no significado da Constituição realizada por alguns autores; e, por fim, realizar um levantamento das principais críticas endereçadas ao Constitucionalismo Popular; expondo, desta maneira, o estado da arte sobre o tema.

O objetivo da pesquisa consiste em debater sobre um possível ponto de equilíbrio que não permita uma "tirania da maioria" na interpretação da Constituição, temida por muitos (explanaremos a este respeito ao longo do trabalho), e, ao mesmo tempo, fomentar a discussão que traga luzes para uma melhora institucional da participação popular nas decisões constitucionais, abandonando uma visão simplista e idealizada dos juízes.

Desta forma, na Parte I do artigo, realizaremos uma contextualização introdutória do constitucionalismo norte-americano pontuando às discussões que são tratadas pelo constitucionalismo popular. Na Parte II, trataremos diretamente do Constitucionalismo Popular, apresentando seus principais autores e buscando seus pontos em comum, bem como conceitos para esta corrente do pensamento constitucional. Na parte III, discutiremos modelos que já foram apresentados por autores norte-americanos de como aproximar a participação popular da interpretação constitucional. Na parte IV, expomos críticas ao constitucionalismo popular, citando autores que se opõem a ele. Por fim, chegaremos às considerações finais.

\section{PANORAMA GERAL DA QUESTÃO DO JUDICIAL REVIEW NOS ES- TADOS UNIDOS}

Não é totalmente inválida a observação de que, ao declarar o que deve ser a lei suprema do país, a própria Constituição é a primeira a ser mencionada, e não as leis dos Estados Unidos genericamente, mas apenas aquelas feitas em conformidade com a Constituição, há esta ordem.

Assim, a particular fraseologia da Constituição dos Estados Unidos confirma e intensifica o princípio, suposto de ser essencial a toda Constituição escrita, que a lei repugnante à Constituição é nula, e a Corte, como os demais departamentos, está vinculada a este instrumento. $^{2}$

\footnotetext{
${ }^{2}$ Caso Marbury v. Madison (UNITED STATES. Supreme Court of United States Marbury V. Madison, tradução nossa. Disponível em: <https://supreme.justia.com/cases/federal/us/5/137/case.html>. Acesso em: 22 de julho de 2017).
} 
Com estas palavras, John Marshall declarou inconstitucional o art. 13 da Lei Judiciária de 1789, no caso Marbury v. Madison, afirmando a Supremacia da Constituição, tornando a decisão emblemática no que tange à consagração da revisão judicial (judicial review).

A discussão sobre a competência da Corte para declarar a inconstitucionalidade de atos emanados pelo Congresso foi, de certa forma, aberta em razão de uma omissão dos constituintes, que não afirmaram, ao menos de forma inequívoca, que a Suprema Corte possuiria esta competência.

Westin sintetiza a posição dos comentaristas sobre as intenções dos constituintes em quatro grupos:

$1^{\circ}$ Os constituintes decidiram conscientemente que o Judiciário teria o poder de julgar os atos do Congresso, e isto afirmaram com palavras expressas no texto da Constituição.

$2^{\circ}$ Os constituintes julgaram, conscientemente, que tal poder decorreria, por dedução normal, dos demais poderes conferidos à Côrte e da lógica de uma Constituição escrita definindo um governo com limitação de poderes.

$3^{\circ}$ Os constituintes ficaram indecisos sobre se deveriam outorgar à Côrte o poder de revisão. A Convenção terminou os trabalhos sem uma resolução consciente sobre a matéria, e os convencionais se separaram com opiniões diferentes sobre se a revisão pelo Judiciário seria admitida ou não.

$4^{\circ}$ Os constituintes examinaram a questão da revisão pelo Judiciário e decidiram omiti-la da Constituição, porque a maioria não estava convencida de seu acerto ou necessidade. $^{3}$

Sendo assim, a questão relativa à intenção original dos constituintes estadunidenses, tão reverenciados, permanece aberta e mal resolvida ao ponto de existirem posições extremamente antagônicas como a de que a Constituição expressamente afirma o judicial review e a de que a competência fora omitida, porque os constituintes não estavam convencidos de sua necessidade.

Para dificultar, ainda mais, a questão, John Marshall, em sua decisão em Marbury v. Madison, fez uma sustentação de pura lógica constitucional, não discutindo aspectos históricos como as práticas em tempos coloniais, debates durante a Convenção e a Ratificação. ${ }^{4}$

\footnotetext{
${ }^{3}$ WESTIN, Alan F. Introdução. In: BEARD, Charles A. A Suprema Côrte e a Constituição. Trad. Paulo Moreira da Silva. Rio de Janeiro: Forense, 1965. p. 13.

${ }^{4}$ WESTIN, Alan F. Introdução. In: BEARD, Charles A. A Suprema Côrte e a Constituição. Trad. Paulo Moreira da Silva. Rio de Janeiro: Forense, 1965. p. 16.
} 
A partir da década de 1880 em diante, houve um grande crescimento da pesquisa histórica a este respeito como de William M. Meigs ${ }^{5}$, George Bancroft ${ }^{6}$ e Charles Beard ${ }^{7}$. Modernamente, encontramos, por exemplo, Larry Kramer. ${ }^{8}$ Os norte-americanos possuem forte apego à discussão relativa aos fundadores dos Estados Unidos, cujo debate é interminável.

A polêmica a respeito é tão complexa que acaba sendo pluripartidária e até mesmo pluri-ideológica, fazendo partidários tanto da direita, quanto da esquerda, liberais ou conservadores, defenderem ou questionarem o controle de constitucionalidade. Muitas das vezes, estas posições se confundem com satisfações ou insatisfações com decisões particulares, o que coloca um componente emocional bastante forte. $A$ história dos Estados Unidos comprova esta diversidade e confusão de posicionamentos ao longo da evolução das decisões da Suprema Corte dos Estados Unidos, apresentando, inclusive, momentos bastante conturbados.

Na primeira metade do século XX, até pouco depois do New Deal, eram os progressistas que se queixavam do ativismo judicial ocorrido na Suprema Corte em sede de controle de constitucionalidade. Neste período, a Suprema Corte declarou como inconstitucionais diversas leis consideradas progressistas.

O caso emblemático desta onda conservadora foi Lochner v. New York ${ }^{9}$. Nesta, a Corte declarou uma lei de Nova lorque que fixava a jornada máxima de dez horas nas padarias, considerando que era uma interferência indevida na liberdade do contrato ${ }^{10}$. Conforme relata Westin, este modo de agir, se seguiu em outras decisões, como Adair v. United States (1908), em que fora invalidada lei federal que punia empresas ferroviárias que obrigassem os trabalhadores a sair dos sindicatos e Hammer v. Dagenhart (1918) em que se anulou "a lei federal que regulava o trabalho de menores em estabelecimentos manufatureiros dedicados ao comércio interestadual"11.

A continuação desta resistência, posteriormente, levou a uma das maiores crises da Suprema Corte dos Estados Unidos. A Corte, na década de 30, continuou seu

\footnotetext{
${ }^{5}$ MEIGS, William M. The Relation of the Judiciary to the Constitution. New York: The Neale Publishing Company, 1919. Disponível em: <https://archive.org/details/relationjudicia00meiggoog>. Acesso em: 21 de julho de 2017.

${ }^{6}$ BANCROFT, George. History of the Constitution of the United States. New York: D. Appleton and Company, 1882. Disponível em: <https://archive.org/details/historyofformati01banc>. Acesso em: 21 de julho de 2017.

${ }^{7}$ BEARD, Charles A. A Suprema Côrte e a Constituição. Tradução de Paulo Moreira da Silva. Rio de Janeiro: Forense, 1965.

${ }^{8}$ KRAMER, Larry. The people themselves. Kindle Edition. Oxford: Oxford University Press, 2004.

${ }^{9}$ UNITED STATES OF AMERICA. Supreme Court of United States. Lochner v. New York. Disponível em: $<$ https:// supreme.justia.com/cases/federal/us/198/45/case.html>. Acesso em: 22 de julho de 2017.

${ }^{10}$ RODRIGUES, Lêda Boechat. A Corte Suprema e o Direito Constitucional Americano. 2. ed. Rio de Janeiro: Civilização Brasileira, 1992. p. 130.

${ }^{11}$ WESTIN, Alan F. Introdução. In: BEARD, Charles A. A Suprema Côrte e a Constituição. Trad. Paulo Moreira da Silva. Rio de Janeiro: Forense, 1965. p. 30.
} 
ativismo e declarou a inconstitucionalidade de leis que buscavam a recuperação econômica dos Estados Unidos frente à crise. Em razão desta atuação, surgiram duas propostas: 1) sustentada por Roosevelt e denominada por court-packing, propunha, por intermédio de lei, o aumento no tamanho da Corte e aposentadoria dos ministros de mais de 70 anos, para a nomeação de novos juízes; 2) proposta por setores do Congresso, visava retirar da Suprema Corte a "última palavra", permitindo que o Legislativo poderia discutir definitivamente a revisão judicial. ${ }^{12}$

No entanto, nenhuma das propostas foram concretizadas. Em 1937, no caso West Coast Hotel Co. v. Parrish, em uma decisão de cinco votos a quatro, a Corte mudou sua orientação jurisprudencial e declarou a constitucionalidade de uma lei que estabelecia o salário mínimo para mulheres. ${ }^{13}$

Contudo, a partir da década de 50, os ventos mudaram e a Corte que, antes de 1937 era considerada ativista e conservadora, passou a ser ativista e progressista. Neste contexto, os papéis se inverteram e, então, os conservadores é que passaram a ser os críticos da revisão judicial ${ }^{14}$.

Esta mudança tem como início o caso Brown v. Board v. Education, que reverteu a doutrina "separados, mas iguais", defendendo uma maior igualdade racial e questionamento da segregação racial ${ }^{15}$. Esta nova onda progressista se tornou ainda mais polêmica depois das decisões em Griswold v. Connecticut e Roe v. Wade. O primeiro declarou a inconstitucionalidade de uma lei de Connecticut que criminalizava o uso de anticoncepcionais, enquanto, o segundo permitiu o aborto em até 3 meses de gestação. Em ambas, sustentaram-se as decisões no direito à intimidade, implícito em vários dispositivos do texto constitucional.

No entanto, apesar desta inversão entre liberais e conservadores nos postos de críticos do judicial review, uma corrente constitucionalista acadêmica norte-americana

\footnotetext{
${ }^{12}$ JÁCOME, Jorge González. ¿El poder para la gente? Una introducción a los debates sobre el Constitucionalismo popular.... In: CHEMERINSKY, Erwin; PARKER, Richard D.; JÁCOME, Jorge González. Constitucionalismo Popular. Bogotá: Siglo del Hombre Editores, 2011. p. 21-22.

${ }^{13}$ JÁCOME, Jorge González. ¿El poder para la gente? Una introducción a los debates sobre el Constitucionalismo popular.... In: CHEMERINSKY, Erwin; PARKER, Richard D.; JÁCOME, Jorge González. Constitucionalismo Popular. Bogotá: Siglo del Hombre Editores, 2011. p. 22.

${ }^{14}$ CHEMERINSKY, Erwin. In defense of judicial review: The perils of popular constitutionalism. University of Illinois Law Review, Champaign, n. 3. p. 673-690, 2004. Disponível em: <http://scholarship.law.duke.edu/cgi/ viewcontent.cgi?article=2144\&context=faculty_scholarship >. Acesso em: 29 de julho de 2017.

kramer discorda que os conservadores tenham se tornado críticos da revisão judicial, apontando que poucos conservadores rejeitaram a revisão judicial, tendo a maioria defendido a prática de uma supremacia judicial. Segundo ele, os autores liberais possuíam mais dificuldade em se posicionar com relação ao ativismo da Corte Warren (KRAMER, Larry. Popular Constitutionalism, Circa 2004. California Law Review, Berkeley, v. 92. p. 9591012, jul. 2004. p. 965 e 967).

${ }^{15}$ JÁCOME, Jorge González. ¿El poder para la gente? Una introducción a los debates sobre el Constitucionalismo popular.... In: CHEMERINSKY, Erwin; PARKER, Richard D.; JÁCOME, Jorge González. Constitucionalismo Popular. Bogotá: Siglo del Hombre Editores, 2011. p. 24-25.
} 
tem causado grande rebuliço no debate constitucional contemporâneo, trata-se do Constitucionalismo Popular.

\section{O CONSTITUCIONALISMO POPULAR}

Difícil tarefa é a de trazer uma definição para o Constitucionalismo Popular. Chemerensky, crítico desta corrente, afirma que nem os constitucionalistas populares conseguem se definir, havendo diferentes visões entre os próprios autores. ${ }^{16}$

Uma forma de tentar definir o constitucionalismo popular, é trazida por Larry Kramer ao opor o conceito de constitucionalismo popular com constitucionalismo legal. Em um sistema de constitucionalismo popular o povo não estaria confinado a atos constituintes ocasionais, mas estaria ativamente incluído na interpretação e efetividade do direito constitucional. Já, no constitucionalismo legal, a autoridade última de interpretação e de efetividade estaria no Judiciário, que possuiria a "palavra final"17. E, ainda, conforme o mesmo autor, o constitucionalismo popular defende que a interpretação jurídica autorizada possa acontecer não apenas nos tribunais, mas, antes, pressupõe que um processo de interpretação igualmente válido possa ser empreendido nos poderes políticos. ${ }^{18}$

Mark Tushnet apresenta um conceito de Constitucionalismo Popular como sendo um processo dialógico. Neste, o povo mobilizado, seus representantes políticos e as Cortes oferecem suas interpretações constitucionais ao mesmo tempo. Sendo assim, a interação de todos estes atores produziria direito constitucional. No entanto, a principal diferença do constitucionalismo popular é que neste as Cortes não são protagonistas no diálogo. Neste modelo, o povo e os Poderes Legislativo e Executivo podem aceitar decisões da Corte, mas podem, contudo, também rejeitá-las, ignorando o que fora decidido pelo Judiciário ${ }^{19}$. Em Taking the Constitution away from the Courts, Mark Tushnet afirma que o Constitucionalismo Popular "se baseia na ideia de que todos nós deveríamos participar na criação de direito constitucional através de nossas ações na política"20.

\footnotetext{
${ }^{16}$ CHEMERINSKY, Erwin. In defense of judicial review: The perils of popular constitutionalism. University of Illinois Law Review, Champaign, n. 3. p. 673-690, 2004. Disponível em: <http://scholarship.law.duke.edu/cgi/ viewcontent.cgi?article=2144\&context=faculty_scholarship >. Acesso em: 29 de julho de 2017. p. 675-676.

${ }^{17}$ KRAMER, Larry. Popular Constitutionalism, Circa 2004. California Law Review, Berkeley, v. 92. p. 959, jul. 2004.

${ }^{18}$ KRAMER, Larry. Democracia Deliberativa e Constitucionalismo Popular: James Madison e o "Interesse do Homem". In: BIGONHA, Antonio Carlos; MOREIRA, Luiz (org.). Limites do Controle de Constitucionalidade. Rio de Janeiro: Lumen Juris, 2009. p. 89. Tradução de Adauto Villela.
}

${ }^{19}$ TUSHNET, Mark V. Popular Constitutionalism As Political Law. Chicago-Kent Law Review, Chicago, v. 81. p. 999-1000, 2006.

${ }^{20}$ TUSHNET, Mark.Taking the Constitution away from the Courts. Kindle Edition. Princeton: Princeton University Press, 1999, posição 2338, tradução nossa. Em razão da inexistência de regras da ABNT acerca da citação 
David Pozen categoriza o constitucionalismo popular em três correntes de pensamento. O primeiro é o Constitucionalismo popular modesto que aceita que as Cortes derrubem leis e preferências majoritárias ocasionalmente, no entanto, defendem que isto não interrompa o diálogo constitucional, devendo os atores extrajudiciais, inclusive o próprio povo, se manifestar sobre as decisões e participar do processo decisório. Ou seja, a partir deste pensamento, a Corte não deve ser vista como um "oráculo com o monopólio da verdade constitucional", devendo o povo se manifestar de forma mais próxima às Cortes, criticando-a quando discordar e tomando ação quando discordar fortemente. ${ }^{21}$

A segunda corrente do Constitucionalismo Popular seria o Constitucionalismo Popular Robusto. Esta defende o encolhimento do poder de revisão judicial, procurando não apenas eliminar a supremacia judicial, mas a interpretação judicial como prevalecente na cultura constitucional. Alguns, como Mark Tushnet, chegariam a defender a total eliminação da revisão judicial. ${ }^{22}$

A terceira corrente, cuja caracterização como Constitucionalismo Popular é bastante duvidosa, é o Departamentalismo. Segundo esta, os três poderes deveriam realizar uma interpretação constitucional coordenada, não havendo uma autoridade independente para interpretar a Constituição. O próprio Pozen afirma, no entanto, que diversos autores afirmam que o Departamentalismo não é uma forma de Constitucionalismo Popular, já que não foca no povo propriamente dito, mas em seus representantes. ${ }^{23}$

Os principais autores do Constitucionalismo Popular são normalmente apontados como sendo: Larry Kramer, Richard Parker, Jeremy Waldron e Mark Tushnet.

Larry Kramer é talvez quem tenha dado maior contribuição bibliográfica ao constitucionalismo popular. Helen Knowles e Julianne A. Toia apontam, com base em dados, que o número de trabalhos acadêmicos sobre o tema cresceu muito depois da obra The People Themselves: Popular Constitutionalism and Judicial Review ${ }^{24}$.

Kramer realiza uma abordagem histórica, defendendo que o constitucionalismo popular sempre foi a intenção dos fundadores da nação norte-americana. Segundo sua

\footnotetext{
de livros eletrônicos e a falta de organização em páginas da maioria das obras no formato Kindle, adotar-se-á a citação por "posição" e não por página (já que esta, na maioria das vezes, não existe neste formato).

${ }^{21}$ POZEN, David E. Judicial Elections as Popular Constitutionalism. Columbia Law Review, New York, v. $110, \mathrm{n}$. 8. p. 2047-2134, dec. 2010. p. 2060-2061.

${ }_{22}$ POZEN, David E. Judicial Elections as Popular Constitutionalism. Columbia Law Review, New York, v. 110, n. 8. p. 2047-2134, dec. 2010. p. 2061-2062.

${ }^{23}$ POZEN, David E. Judicial Elections as Popular Constitutionalism. Columbia Law Review, New York, v. $110, \mathrm{n}$. 8. p. 2047-2134, dec. 2010. p. 2063.

${ }^{24}$ Cf. KNOWLES, Helen J.; TOIA, Julianne A. Defining "Popular Constitutionalism": The Kramer Versus Kramer Problem. Southern University Law Review, Baton Rouge. p. 1-40, 9 abr. 2014. Disponível em: <https://ssrn. com/abstract=2395465>. Acesso em: 17 de setembro de 2017.
} 
concepção: "na era da Fundação era diferente. Naquela época, o poder de interpretar (e não apenas o poder de criar) a norma constitucional, pensava-se, residir com o povo".25

Em The People Themselves, sua principal obra bibliográfica sobre o tema, realiza ampla revisão histórica defendendo que o pensamento constitucional americano que prevaleceu durante grande parte da história norte-americana, mas sobretudo nas primeiras décadas, foi o do constitucionalismo popular.

Segundo ele, os fundadores dos Estados Unidos estavam profundamente comprometidos a criar um sistema constitucional cujo protagonista seria o povo, que concederia ao governo direção e energia. A invocação do "povo", desta forma, não era meramente retórica, mas expressava os sentimentos e objetivos dos líderes americanos $^{26}$. Conforme suas próprias palavras: "Constitutionalismo americano designou aos cidadãos comuns a função central e crucial na implementação constitucional"27. Assim, a "palavra final" em matéria constitucional residiria no povo. ${ }^{28}$

O autor ressalta em diversos trechos da obra, no entanto, que, o Constitucionalismo Popular não se opõe à revisão judicial, mas defende, todavia, que a interpretação constitucional realizada pelo Judiciário não está acima daquela realizada por outros Poderes, e que todas estas formas de interpretação, inclusive a judicial, estariam subordinadas ao entendimento do povo ${ }^{29}$. Desta maneira, a oposição do Constitucionalismo Popular, segundo Kramer, não está em relação à revisão judicial, mas à supremacia judicial.

Helen Knowles e Julianne Toia demonstram que muitos trabalhos acadêmicos confundem o propósito de Kramer, apontando que este faria a crítica da revisão judicial, quando, no entanto, o enfrentamento se dá em relação à supremacia judicial. Este desentendimento dos objetivos de Kramer deu ao Constitucionalismo Popular ares de radicalismo que não necessariamente representa o movimento ${ }^{30}$. Kramer deixa bem claro em seu livro que o constitucionalismo popular, em sua concepção, nunca negou às Cortes o seu poder de revisão, mas negava o poder dos juízes de falar por último ${ }^{31}$.

Voltando à revisão histórica de Kramer, o constitucionalista relata que, ao criarem a Constituição Americana de 1787, os constituintes pouco se preocuparam com o judicial review em nível federal, havendo apenas certa aceitação no que dizia respeito à

\footnotetext{
${ }^{25}$ KRAMER, Larry. "Democracia Deliberativa e Constitucionalismo Popular: James Madison e o "Interesse do Homem". In: BIGONHA, Antonio Carlos; MOREIRA, Luiz (org.). Limites do Controle de Constitucionalidade. Rio de Janeiro: Lumen Juris, 2009. p. 87. Tradução de Adauto Villela.

${ }^{26}$ KRAMER, Larry. The people themselves. Kindle Edition. Oxford: Oxford University Press, 2004. p. 6-7.

${ }^{27}$ KRAMER, Larry. The people themselves. Kindle Edition. Oxford: Oxford University Press, 2004. p. 8, tradução nossa.

${ }^{28}$ KRAMER, Larry. The people themselves. Kindle Edition. Oxford: Oxford University Press, 2004. p. 8 e 208.

${ }^{29}$ KRAMER, Larry. The people themselves. Kindle Edition. Oxford: Oxford University Press, 2004. p. 8 e 60.

${ }^{30}$ KNOWLES, Helen J.; TOIA, Julianne A. Defining "Popular Constitutionalism": The Kramer Versus Kramer Problem. Southern University Law Review, Baton Rouge. p. 21, 9 abr. 2014. Disponível em: <https://ssrn.com/ abstract $=2395465>$. Acesso em: 17 de setembro de 2017.

${ }^{31}$ KRAMER, Larry. The people themselves. Kindle Edition. Oxford: Oxford University Press, 2004. p. 208.
} 
revisão judicial de leis estaduais ${ }^{32}$. Entendia-se, no período constituinte, que o controle constitucional seria realizado pelo povo através da política, utilizando-se de diversos meios como as eleições, júris, protestos populares, etc ${ }^{33}$.

Kramer afirma que os fundadores daquela nação, tanto Federalistas quanto Anti-Federalistas, reconheciam os perigos que "inclinações majoritárias" poderiam causar nas legislaturas. No entanto, para resolver este problema, optaram por retardar o processo político estabelecendo um sistema de pesos e contrapesos ${ }^{34}$.

A questão da revisão judicial, no entanto, passou a ganhar mais espaço a partir da década de 1790, sem que, contudo, houvesse um clamor para que as Cortes tivessem uma especial ou exclusiva responsabilidade em interpretar a Constituição ${ }^{35}$. O Judiciário possuiria o dever de declarar nula a lei inconstitucional, assim como os outros Poderes também possuiriam este dever, endossando a teoria departamentalista ${ }^{36}$, anteriormente mencionada.

Com o passar do tempo é que a teoria da revisão judicial começou a se tornar mais ambiciosa, levando ao que, modernamente, entendemos como modelo de supremacia judicial. Já, na época da decisão de Marbury v. Madison (1803), alguns federalistas defendiam algo próximo ao que se entende por supremacia judicial.

Contudo, para Kramer, a decisão em Marbury v. Madison apenas consagrava a revisão judicial e não a supremacia, já que Marshall, em seu voto, não disse que interpretar a Constituição era dever apenas das Cortes, mas que "a Corte, assim como, os outros departamentos está vinculada" à Constituição. ${ }^{37}$

No decorrer das décadas, entretanto, a ideia da supremacia judicial foi ganhando espaço gradualmente. Em 1958, a Suprema Corte dos Estados Unidos, no caso Cooper v. Aaron, afirmou explicitamente a supremacia da interpretação judicial. Neste período, já se conseguia perceber que a ideia de supremacia constitucional já era amplamente aceita. $A$ partir da década de 1960, passou-se a questionar as decisões das Cortes, enquanto a postura de negar a "palavra final" à Suprema Corte acabou praticamente desaparecendo. ${ }^{38}$

\footnotetext{
${ }^{32}$ KRAMER, Larry. The people themselves. Kindle Edition. Oxford: Oxford University Press, 2004. p. 73-77.

${ }^{33}$ KRAMER, Larry. The people themselves. Kindle Edition. Oxford: Oxford University Press, 2004. p. 83.

${ }^{34}$ KRAMER, Larry. The people themselves. Kindle Edition. Oxford: Oxford University Press, 2004. p. 80.

${ }^{35}$ KRAMER, Larry. The people themselves. Kindle Edition. Oxford: Oxford University Press, 2004. p. 98.

${ }^{36}$ KRAMER, Larry. The people themselves. Kindle Edition. Oxford: Oxford University Press, 2004. p. 106.

${ }^{37}$ KRAMER, Larry. The people themselves. Kindle Edition. Oxford: Oxford University Press, 2004. p. 125-126, tradução nossa. Neste sentido de Kramer, Mark Tushnet afirma que são possíveis duas interpretações do caso Marbury v. Madison. A primeira trata a atuação da corte em declarar a inconstitucionalidade de leis sem implicar em superioridade em relação aos outros Poderes, que possuem o mesmo dever. Já a segunda, encara não apenas a Constituição como suprema, mas também a interpretação constitucional das Cortes (TUSHNET, Mark. Taking the Constitution away from the Courts. Kindle Edition. Princeton: Princeton University Press, 1999, posição 114-117).

${ }^{38}$ KRAMER, Larry. The people themselves. Kindle Edition. Oxford: Oxford University Press, 2004. p. 106. KRAMER, Larry. The people themselves. Kindle Edition. Oxford: Oxford University Press, 2004. p. 221.
} 
Além de Larry Kramer, encontramos, no Constitucionalismo Popular, Jeremy Waldron, que realiza uma diferenciação entre revisão judicial forte e revisão judicial fraca. No modelo de revisão judicial forte, o Judiciário possui o poder de definir que determinada lei não será aplicada, tornando-a letra morta. Já em um modelo de revisão judicial fraca, as Cortes podem aferir se as leis estão em conformidade com os direitos individuais, mas não podem se negar a aplicá-las. Cita como exemplo de revisão judicial fraca o caso do Reino Unido em que, apesar da decisão judicial não afetar a validade da lei, nem obrigar outras autoridades, estas últimas podem vir a rever a decisão a partir da declaração de incompatibilidade proferida pelo Judiciário, até mesmo através de um processo legislativo mais rápido para corrigir a incompatibilidade. Waldron deixa claro que a sua crítica à revisão judicial se limita apenas ao modelo de revisão judicial forte. ${ }^{39}$

Outra fonte de críticas importante é Richard Parker, que apresenta uma abordagem discursiva, para defender o constitucionalismo popular. O autor foca no que ele chama de energia política do povo comum (political energy of ordinary people), se referindo à participação das pessoas, da coletividade em geral, na política ${ }^{40}$. Diz Parker que sobre esta participação das pessoas comuns, é possível ter-se duas posições: a "Sensibilidade Populista" e a "Sensibilidade Anti-Populista".41

Segundo ele, a Sensibilidade Anti-Populista, que iremos chamar aqui de Posicionamento Anti-Populista, enxerga a energia política do povo comum como um

${ }^{39}$ WALDRON, Jeremy. The core of the case against judicial review. The Yale Law Review, New Haven, v. 115. p. 1354-1355, 2006.

o posicionamento contra a revisão judicial forte de Jeremy Waldron, no entanto, é condicionado a quatro premissas: 1. as instituições democráticas estão funcionando razoavelmente, com representação no Poder Legistativo eleita por sufrágio universal; 2 . um conjunto de instituições judiciais, formadas por membros não eleitos e que estão destinados para acompanhar disputas e fazer valer o estado de direito; 3. um comprometimento da maior parte da sociedade no sentido de fazer valer os direitos individuais e os direitos das minorias; 4 . a existência de um desacordo de boa-fé sobre estes direitos. A questão, todavia, se torna complexa quando ao menos uma destas premissas não está encontrada. Ocorrendo, isto, Jeremy Waldron afirma que não necessariamente será o caso de apoiar a existência de revisão judicial, já que é possível que o Poder Judiciário em nada possa contribuir a depender da falha institucional existente (WALDRON, Jeremy. The core of the case against judicial review. The Yale Law Review, New Haven, v. 115. p. 1360 e 1402, 2006). Em seminário sobre controle constitucional e política ocorrido no Tribunal Constitucional da Colômbia, Jeremy Waldron afirma que o posicionamento contra a revisão judicial forte deve levar em conta algumas circunstâncias próprias de cada país. Uma delas é o desempenho e reputação do Poder Legislativo e que corpos legislativos corruptos e de pouca representatividade aumentam a legitimidade da jurisdição constitucional para atuar. Assim, Waldron aceita que os argumentos contra a revisão judicial forte não podem ser absolutos, mas relativizados em certas circunstâncias (Cf. Profesor Jeremy Waldron de la Universidad de Nueva York, en la Corte Constitucional, seminario sobre control de constitucionalidad y política. Publicado por: Corte Constitucional. Bogotá: Tribunal Constitucional da Colômbia, 2017. Youtube (1h40min). Disponível em: <https://www.youtube.com/watch?v=8I_WGqY3qMA $>$. Acesso em: 23 de setembro de 2017).

${ }^{40}$ Cf. PARKER, Richard Davies. "Here, the people rule": a constitutionalist populist manifesto. Valparaíso University Law Review, Valparaíso, v. 27, n. 3. p. 531-584, 1993. Disponível em: <https://dash.harvard.edu/handle/1/12967873>. Acesso em: 23 de julho de 2017.

${ }^{41}$ PARKER, Richard Davies. "Here, the people rule": a constitutionalist populist manifesto. Valparaíso University Law Review, Valparaíso, v. 27, n. 3. p. 552-553, 1993. Disponível em: <https://dash.harvard.edu/handle/1/12967873>. Acesso em: 23 de julho de 2017. 
problema, como uma ameaça à paz e risco à opressão. Esta forma de enxergar o povo o veria como uma multidão de "qualidade inferior" e de embasamento político menos refinado. Para Parker, este posicionamento anti-populista veria uma elite como racional, bem informada, complexa, de visão a longo prazo, com espírito público e de mente aberta, enquanto o "povo ordinário" seria emocional, impulsivo, ignorante, egoísta, ensimesmado e mente fechada. Para os que pensam assim, o povo possui dois problemas: além de fazer política de baixa qualidade, é perigoso ${ }^{42}$.

Já o Posicionamento Populista (Sensibilidade Populista) veria a ausência da energia política do povo comum como um problema, uma passividade popular, sendo, desta forma, um mal. Para os que possuem este modo de ver, a participação do povo comum melhora a qualidade do governo e é essencial para evitar a opressão. Enquanto os Populistas veem a participação popular como algo positivo e o insulamento como um problema, os Anti-Populistas enxergam exatamente o contrário. ${ }^{43}$

Parker encara o contramajoritarismo, ou seja, a ideia de que o Direito Constitucional possui uma função de contrapeso à regra majoritária da democracia, como um clichê $\hat{e}^{44}$. Além disso, Parker sustenta que o Constitucionalismo contemporâneo se baseia em dois grandes fetiches: 1) a ideia de que a Constituição apresenta sempre um significado "correto" e não uma variedade de interpretações possíveis; 2) a superioridade qualitativa do Direito Constitucional, que é vital e vulnerável, podendo qualquer infecção realizada pela política ordinária levar a um completo desastre. ${ }^{45}$

Encara a "tirania da maioria" como um exagero ridículo. Segundo ele, a maior parte da opressão é realizada por minorias, ou melhor, uma espécie de elite ou minoria elitista ${ }^{46}$. Seguindo raciocínio de Richard Parker, Kramer concorda dizendo que boa parte dos defensores da supremacia judicial apresentam um medo da política popular, acreditando ser perigosa e arbitrária. Segundo Kramer, "a tirania da maioria" seria meramente um slogan. ${ }^{47}$

\footnotetext{
${ }^{42}$ PARKER, Richard Davies. "Here, the people rule": a constitutionalist populist manifesto. Valparaíso University Law Review, Valparaíso, v. 27, n. 3. p. 552-554, 1993. Disponível em: <https://dash.harvard.edu/handle/1/12967873>. Acesso em: 23 de julho de 2017.

${ }^{43}$ PARKER, Richard Davies. "Here, the people rule": a constitutionalist populist manifesto. Valparaíso University Law Review, Valparaíso, v. 27, n. 3. p. 552 e 556, 1993. Disponível em: <https://dash.harvard.edu/handle/1/12967873>. Acesso em: 23 de julho de 2017.

${ }^{44}$ PARKER, Richard Davies. "Here, the people rule": a constitutionalist populist manifesto. Valparaíso University Law Review, Valparaíso, v. 27, n. 3. p. 558, 1993. Disponível em: <https://dash.harvard.edu/handle/1/12967873>. Acesso em: 23 de julho de 2017.

${ }^{45}$ PARKER, Richard Davies. "Here, the people rule": a constitutionalist populist manifesto. Valparaíso University Law Review, Valparaíso, v. 27, n. 3. p. 564-565, 1993. Disponível em: <https://dash.harvard.edu/handle/1/12967873>. Acesso em: 23 de julho de 2017.

${ }^{46}$ PARKER, Richard Davies. "Here, the people rule": a constitutionalist populist manifesto. Valparaíso University Law Review, Valparaíso, v. 27, n. 3. p. 569-570, 1993. Disponível em: <https://dash.harvard.edu/handle/1/12967873>. Acesso em: 23 de julho de 2017.

${ }^{47}$ KRAMER, Larry. Popular Constitutionalism, Circa 2004. California Law Review, Berkeley, v. 92. p. 1004-1006, jul. 2004.
} 
Kramer ilustra este debate através de um diálogo criado por James Madison em um ensaio denominado Who are the Best Keepers of the People's Liberties? ${ }^{48}$. Neste, Madison cria dois personagens: um Republicano e um Anti-Republicano. O Republicano responderia à pergunta de "Quem é o melhor guardião das liberdades do povo?", dizendo: "o próprio povo" ("[t]he People Themselves"). Em seguida, o anti-republicano replicaria: "O povo é estúpido, suspeito e licencioso", "não se pode neles confiar" e ainda que "quanto mais você faz do governo independente e hostil em relação ao povo, melhor segurança confere aos direitos e interesses das pessoas". Concluindo, Kramer afirma que os defensores da supremacia judicial seriam os aristocratas de hoje ${ }^{49}$.

Aliás, Richard Parker afirma que sequer existe algo como "a maioria". O autor afirma que a ideia de regra da maioria é falha em razão da transformação de maiorias em coalisões que representam grupos de interesses, atuando distanciados do envolvimento e influência do "povo ordinário".50

O mais "radical" dos constitucionalistas populares, no entanto, talvez seja Mark Tushnet. O autor não apenas rejeita a noção de supremacia judicial, como defende a extinção do modelo de revisão judicial. Apresenta esta ideia de forma explícita em seu livro Taking the Constitution away from the Courts, cujo capítulo 7 se intitula Against Judicial Review ${ }^{51}$. Em breve comentário de 2011, idealiza uma proposta de emenda constitucional com as seguintes palavras: "The constitutionality of acts of Congress shall not be reviewed by any court in the United States". Esta redação seria inspirada no artigo 120 da Constituição dos Países Baixos em que: "The constitutionality of Acts of Parliament and treaties shall not be reviewed by the courts"52.

No entanto, como demonstrado, o alvo em comum que pode ser identificado no Constitucionalismo Popular é a "supremacia judicial". A revisão judicial acaba sendo um alvo a depender do pensamento específico de cada autor, de onde se conclui que existe uma razoável variação nesta corrente do constitucionalismo americano.

\footnotetext{
${ }^{48} \mathrm{Cf}$. MADISON, James. Who Are the Best Keepers of the People's Liberties?.National Gazette, 22 dec. 1792. Disponível em: <http://www.constitution.org/jm/17921222_keepers.htm>. Acesso em: 23 de julho de 2017.

${ }^{49}$ KRAMER, Larry. Popular Constitutionalism, Circa 2004. California Law Review, Berkeley, v. 92. p. 1007-1008, jul. 2004.

50 PARKER, Richard Davies. "Here, the people rule": a constitutionalist populist manifesto. Valparaíso University Law Review, Valparaíso, v. 27, n. 3. p. 573, 1993. Disponível em: <https://dash.harvard.edu/handle/1/12967873>. Acesso em: 23 de julho de 2017.

${ }^{51}$ TUSHNET, Mark. Taking the Constitution away from the Courts. Kindle Edition. Princeton: Princeton University Press, 1999.

${ }_{52}$ TUSHNET, Mark. Abolishing Judicial Review. Constitutional Commentary, Minneapolis, v. 27. p. 581-589, 2011. Disponível em: <https://conservancy.umn.edu/bitstream/handle/11299/163457/8-Tushnet-273-AbolishingJudicialReview.pdf?sequence=1>. Acesso em: 18 de setembro de 2017.
} 


\subsection{Eleição para Ministros da Suprema Corte}

David Pozen pensa a possibilidade de promoção do constitucionalismo popular através da eleição de juízes. Esta proposta não é nenhuma novidade para os norte-americanos já que a eleição de juízes, inclusive, para Supremas Cortes existe em diversos estados norte-americanos. Segundo Pozen, mais de três quartos dos Estados norte-americanos realizam eleições periódicas para juízes, dando aos cidadãos uma poderosa ferramenta de controle da interpretação constitucional. As Cortes Estaduais julgam muito mais casos que as Cortes Federais e tem uma grande importância em diversos casos polêmicos como, por exemplo, o casamento homoafetivo. Além disso, não expõem apenas as Constituições Estaduais, como também a própria Constituição Federal. ${ }^{53}$

O autor aponta que a eleição de juízes apresenta características e consequências tanto fora da Corte como dentro dela. Das características e consequências fora da Corte, apresenta as seguintes: 1 . O exercício da soberania do povo ao eleger juízes; 2 . Cria um mecanismo de accountability, podendo o povo registrar suas discórdias em relação à atuação judicial; 3. A eleição de juízes como agente de mudanças constitucionais: a alteração dos juízes poderia provocar mudanças na interpretação constitucional; 4. O diálogo entre povo e Judiciário: as eleições de juízes encorajariam que estes tivessem uma maior comunicação com o povo..$^{54}$

Dentro da Corte, os efeitos e características seriam outros: 1. Geraria uma maior contenção da atuação judicial: os juízes atuariam mais como reguladores, minimizando a interferência no processo político, agindo à moda de James Thayer ${ }^{55}$; 2 . Populismo judicial: os juízes incorporarão os credos populares ao tomar suas decisões. ${ }^{56}$

Em uma alternativa bem mais cautelosa, Jonathan Siegel sugere que sejam conferidos mandatos temporários aos ministros da Suprema Corte em vez de mandatos vitalícios como é atualmente. Em um novo modelo, os juízes possuiriam mandatos com termo de oito anos, sendo que um mandato expiraria a cada dois anos. ${ }^{57}$

\footnotetext{
${ }^{53}$ POZEN, David E. Judicial Elections as Popular Constitutionalism. Columbia Law Review, New York, v. 110, n. 8. p. 2047-2134, dec. 2010. p. 2050-2051.

${ }^{54}$ POZEN, David E. Judicial Elections as Popular Constitutionalism. Columbia Law Review, New York, v. 110, n. 8. p. 2047-2134, dec. 2010. p. 2068-2074.

${ }_{55}$ James Thayer, no clássico The Origin and Scope of the American Doctrine of Constitutional Law, escreveu que um ato produzido politicamente só deve ser declarado constitucional "quando aqueles que possuem o direito de produzir leis não apenas cometem um erro, mas cometem um erro bem claro - tão claro que não está aberta a um questionamento racional" (THAYER, James Bradley. The Origin and Scope of The American Doctrine of Constitutional Law. Boston: Little, Brown, and Company, 1893, tradução nossa. Disponível em: <https:// archive.org/details/originandscopea00thaygoog >. Acesso em: 29 de julho de 2017. p. 18). Desenvolvendo, assim, uma espécie de minimalismo.

${ }^{56}$ POZEN, David E. Judicial Elections as Popular Constitutionalism. Columbia Law Review, New York, v. 110, n. 8. p. 2047-2134, dec. 2010. p. 2076-2086.

${ }^{57}$ SIEGEL, Jonathan R. The institutional Case for Judicial Review. lowa Law Review, lowa City, v. 97. p. 1198, 2012.
} 


\subsection{O Constitucionalismo Popular Mediado de Barry Friedman}

A tese de Barry Friedman em Mediated Popular Constitutionalism é que, na verdade, existe, na prática, um Constitucionalismo Popular mediado, isto é, a Suprema Corte segue o entendimento popular, mesmo que isto não ocorra exatamente como sonham os constitucionalistas populares. ${ }^{58}$

Como ocorreria este fenômeno? A teoria se chamaria do "Constitucionalismo Popular Mediado", porque esta influência popular nas decisões da Suprema Corte não seria direta, mas seria "mediada" por outros atores políticos. Estes autores seriam: os agentes políticos, a mídia e as lideranças da sociedade, em geral.

Para chegar a esta conclusão, Friedman se baseia no empirismo das pesquisas das ciências sociais ${ }^{59}$. Esta ideia de que as decisões se baseiam no entendimento popular se sustenta sobre três pilares: 1 . As decisões judicias se assentam sobre uma aceitabilidade da maior parte das pessoas; 2 . Mesmo que o público não apoie certas decisões, ele aceita o judicial review; 3. Se o povo estivesse insatisfeito com o judicial review, ele poderia tomar ação. ${ }^{60}$

Conforme relata Friedman, isto é confirmado por pesquisas empíricas que apontam que as decisões judiciais comportam as preferências majoritárias ou a uma grande pluralidade de pessoas. Outras pesquisas apontam, que mesmo quando há dissonância com o entendimento popular, a opinião majoritária estava evoluindo no sentido adotado da Suprema Corte. ${ }^{61}$

O apontamento de juízes, inclusive os da Suprema Corte, ocorre com certa congruência à opinião popular e às decisões da Suprema Corte. E ainda, os juízes precisam das pessoas. Ter o apoio da opinião popular é a chave para se proteger de ataques dos outros Poderes.

O relacionamento da Suprema Corte com o povo é mediado por três motivos: 1. Juízes não são eleitos; 2 . O povo expressa sua opinião sobre a manutenção da Corte através dos representantes eleitos; 3 . As decisões da Suprema Corte são filtradas pela mídia. ${ }^{62}$

\footnotetext{
${ }^{58}$ FRIEDMAN, Barry. Mediated Popular Constitutionalism. Michigan Law Review, Ann Arbor, v. 101. p. 2597, 2004. Disponível em: <https://www.researchgate.net/profile/Barry_Friedman2/publication/228186449_Mediated_Popular_Constitutionalism/links/0deec52568b6842140000000.pdf >. Acesso em: 29 de julho de 2017. ${ }^{59}$ FRIEDMAN, Barry. Mediated Popular Constitutionalism. Michigan Law Review, Ann Arbor, v. 101. p. 2597 e 2601, 2004. Disponível em: <https://www.researchgate.net/profile/Barry_Friedman2/publication/228186449_ Mediated_Popular_Constitutionalism/links/Odeec52568b6842140000000.pdf>. Acesso em: 29 de julho de 2017. ${ }^{60}$ FRIEDMAN, Barry. Mediated Popular Constitutionalism. Michigan Law Review, Ann Arbor, v. 101. p. 2604, 2004. Disponível em: <https://www.researchgate.net/profile/Barry_Friedman2/publication/228186449_Mediated_Popular_Constitutionalism/links/0deec52568b6842140000000.pdf >. Acesso em: 29 de julho de 2017. ${ }^{61}$ FRIEDMAN, Barry. Mediated Popular Constitutionalism. Michigan Law Review, Ann Arbor, v. 101. p. 2605, 2004. Disponível em: <https://www.researchgate.net/profile/Barry_Friedman2/publication/228186449_Mediated_Popular_Constitutionalism/links/0deec52568b6842140000000.pdf >. Acesso em: 29 de julho de 2017.

${ }^{62}$ FRIEDMAN, Barry. Mediated Popular Constitutionalism. Michigan Law Review, Ann Arbor, v. 101. p. 2611, 2004. Disponível em: <https://www.researchgate.net/profile/Barry_Friedman2/publication/228186449_Mediated_Popular_Constitutionalism/links/Odeec52568b6842140000000.pdf>. Acesso em: 29 de julho de 2017.
} 
Friedman aponta a teoria do suporte, desenvolvida pelo cientista político David Easton, segundo a qual haveria dois tipos de suporte às políticas públicas: um suporte difuso e um suporte específico. Aplicando estes conceitos às decisões judiciais, o suporte difuso estaria relacionado ao apoio popular dado à instituição como um todo, isto é, a impressão de que a instituição está fazendo "um bom trabalho". O suporte específico, em contrapartida, diz respeito a determinadas decisões. ${ }^{63}$

Contudo, em pesquisas posteriores, constatou-se que esta diferenciação entre suporte específico e suporte difuso é bastante difícil, isto porque haveria uma barreira permeável entre ambos. O suporte específico acaba por se confundir com o suporte difuso. Isto ocorre porque o apoio das pessoas à Suprema Corte acaba por se confundir com decisões específicas e este efeito acaba durando um longo tempo. Por exemplo, os cientistas políticos Greg Caldeira e James Gibson identificaram que a opinião em relação ao aborto, ou seja, relativa ao suporte específico, determinava a própria opinião quanto à Corte, isto é, o suporte difuso ${ }^{64}$. Resumindo, determinadas decisões da Suprema Corte acabam influenciando a visão popular da Corte como um todo.

Conforme aponta Friedman, pesquisas sugerem que o povo americano sabe mais sobre as decisões da Suprema Corte do que se pode acreditar. No entanto, o recebimento da informação de como o Judiciário trabalha é mediada por dois atores: a mídia e os líderes políticos. Entretanto, apenas uma pequena fração do trabalho da Suprema Corte vai ao conhecimento do público, apenas uma parcela dos casos chama a atenção da opinião pública. ${ }^{65}$

Por estas razões, Friedman apresenta que existe uma relação entre povo e Judiciário e que esta é mediada.

\section{AS CRÍTICAS AO CONSTITUCIONALISMO POPULAR}

Erwin Chemerinsky realiza uma crítica ao constitucionalismo popular utilizando a bastante debatida, em território americano, função contramajoritária da revisão judicial. A possibilidade de um abuso das maiorias, organizadas na forma de facções, é descrita por Madison, no artigo federalista n. $10^{66}$. Décadas depois, Alexis de Tocqueville

\footnotetext{
${ }^{63}$ FRIEDMAN, Barry. Mediated Popular Constitutionalism. Michigan Law Review, Ann Arbor, v. 101. p. 2612-2613, 2004. Disponível em: <https://www.researchgate.net/profile/Barry_Friedman2/publication/228186449_Mediated_Popular_Constitutionalism/links/Odeec52568b6842140000000.pdf>. Acesso em: 29 de julho de 2017.

${ }^{64}$ FRIEDMAN, Barry. Mediated Popular Constitutionalism. Michigan Law Review, Ann Arbor, v. 101. p. 2615-2617, 2004. Disponível em: <https://www.researchgate.net/profile/Barry_Friedman2/publication/228186449_Mediated_Popular_Constitutionalism/links/0deec52568b6842140000000.pdf>. Acesso em: 29 de julho de 2017.

${ }^{65}$ FRIEDMAN, Barry. Mediated Popular Constitutionalism. Michigan Law Review, Ann Arbor, v. 101. p. 2618-2620, 2004. Disponível em: <https://www.researchgate.net/profile/Barry_Friedman2/publication/228186449_Mediated_Popular_Constitutionalism/links/0deec52568b6842140000000.pdf >. Acesso em: 29 de julho de 2017.

${ }^{66}$ MADISON, James. Federalist No. 10 - The Same Subject Continued:The Union as a Safeguard Against Domestic Faction and Insurrection. In: The Federalist Papers. New York Packet, 23 nov. 1787. Disponível em: <https://
} 
faz abordagem semelhante ao se referir à "tirania da maioria"67. No âmbito da jurisdição constitucional, esta questão ficou consagrada com a expressão "dificuldade contramajoritária" de Alexander Bickel. ${ }^{68}$

Chemerinsky afirma que com o fim da revisão judicial ou da supremacia judicial, os contrapesos em favor das minorias seriam dramaticamente reduzidos, se não eliminados, deixando as minorias dependentes das maiorias. Em se tratando de direitos de minorias, o processo político e o constitucionalismo popular não podem ser confiados. Além disso, o autor teme que as críticas promovidas pelo Constitucionalismo Popular produzam contenção por parte dos juízes progressistas que, temerosos, não avançariam na promoção da igualdade e da liberdade. ${ }^{69}$

Um problema exemplificativo em relação da tensão entre maiorias e minorias é o caso da Proposição 8 (Proposition 8) da Califórnia, citado por JÁCOME70 ao comentar o artigo de Erwin Chemerinsky. Após a Suprema Corte da Califórnia decidir que limitar o casamento de pessoas do mesmo sexo feria a Constituição do Estado, cidadãos californianos formularam a Proposição 8 para emendar aquela Constituição, definindo que casamento seria apenas a união entre homem e mulher. Então, casais do mesmo sexo que desejavam se casar, ajuizaram ação na justiça federal, contra o Governador do Estado e outras autoridades, defendendo a inconstitucionalidade da Proposição 8 perante a Constituição dos Estados Unidos.

Estas autoridades se recusaram a defender a proposição, tendo a Corte Distrital permitido que os peticionários a defendessem. Apesar disso, esta corte defendeu que a Proposição era inconstitucional. Os peticionários recorreram à Nona Corte de apelações (Ninth Court of Appeals), que confirmou a decisão da Corte Distrital pela inconstitucionalidade. A partir disto, o caso foi para a Suprema Corte dos Estados Unidos.

\footnotetext{
www.congress.gov/resources/display/content/The+Federalist+Papers\#TheFederalistPapers-10>. Acesso em: 29 de julho de 2017.

Kramer critica o uso do Federalista n. 10 para defender o controle de constitucionalidade. Segundo ele, o pensamento de James Madison, o federalista não era compatível com a supremacia judicial. Aponta que quando Madison pensou em formas de obstruir as facções, em seu artigo federalista n. 10, ele não citou o Judiciário (Ainda, segundo Kramer, Madison acreditava que era função do povo fiscalizar o governo republicano e que o povo era o verdadeiro soberano em cada governo livre (KRAMER, Larry. "Democracia Deliberativa e Constitucionalismo Popular: James Madison e o "Interesse do Homem". In: BIGONHA, Antonio Carlos; MOREIRA, Luiz (org.). Limites do Controle de Constitucionalidade. Rio de Janeiro: Lumen Juris, 2009. Tradução de Adauto Villela. p. 93-94 e 107).

${ }^{67}$ TOCQUEVILLE, Alexis de. A Democracia na América. São Paulo: Folha de São Paulo, 2010. p. 194.

${ }^{68} \mathrm{BICKEL}$, Alexander. The Least Dangerous Branch. $2^{\mathrm{a}}$ ed. New Haven: Yale University Press, 1986. p. 16-21.

${ }^{69}$ CHEMERINSKY, Erwin. In defense of judicial review: The perils of popular constitutionalism. University of Illinois Law Review, Champaign, n. 3. p. 673-690, 2004. Disponível em: <http://scholarship.law.duke.edu/cgi/ viewcontent.cgi?article=2144\&context=faculty_scholarship >. Acesso em: 29 de julho de 2017. p. 683; 689.

${ }^{70}$ JÁCOME, Jorge González. ¿El poder para la gente? Una introducción a los debates sobre el Constitucionalismo popular.... In: CHEMERINSKY, Erwin; PARKER, Richard D.; JÁCOME, Jorge González. Constitucionalismo Popular. Bogotá: Siglo del Hombre Editores, 2011. p. 53 e 55.
} 
No entanto, a Suprema Corte negou-se a julgar o mérito do caso, ou seja, a constitucionalidade da Proposição 8, por uma questão processual: a inexistência de um caso concreto. Fundamentou-se, assim, no artigo III da Constituição dos Estados Unidos, que exige que haja uma controvérsia real (actual controversy) ${ }^{71}$.

Contudo, os constitucionalistas populares subestimam o problema das minorias, colocando todas as confianças de que não há qualquer risco a elas. Larry Kramer e Richard Parker, sobretudo, acusam aqueles que defendem a supremacia judicial, de aristocratas e de estarem contra o povo. Adotam uma lógica de que se está a favor da supremacia judicial, se está contra o povo. Esta visão caricaturista e bipolarizada, entretanto, é equivocada e não permite pensar modelos que reconheçam a importância da revisão judicial e o contrapeso contramajoritário e, ainda, incentivar a participação popular na interpretação e efetivação da Constituição.

Em uma espécie de "terceira via", estão Robert Post e Reva Siegel. Estes autores acreditam ser possível uma conciliação entre supremacia judicial e constitucionalismo popular, discordando de Kramer o qual acredita que supremacia judicial e constitucionalismo popular são mutuamente excludentes, embora concordem com o autor que existe uma tensão entre supremacia judicial e constitucionalismo popular ${ }^{72}$.

Post e Siegel creem que não há uma mútua exclusão, porque o conceito de supremacia judicial não significa que as cortes podem determinar ou obrigar as convicções dos cidadãos respeito da Constituição. Um cidadão poderia, desta forma, discordar da interpretação da Corte, havendo a possibilidade, inclusive, da decisão da Corte ser vencida por uma emenda à Constituição subsequente. ${ }^{73}$

A Corte, inclusive, a partir da visão de Post e Siegel, seria importante para o constitucionalismo popular, já que para o povo exercer o seu poder de manifestação a respeito dos valores constitucionais é preciso que haja uma defesa da liberdade de

\footnotetext{
${ }^{71}$ UNITED STATES OF AMERICA. Supreme Court of United States. Hollingsworth v. Perry. Disponível em: <https://www.supremecourt.gov/opinions/12pdf/12-144_8ok0.pdf>. Acesso em: 28 de julho de 2017.

${ }_{72}^{72} \mathrm{Em}$ contraste à Kramer, nós não entendemos que supremacia judicial e constitucionalismo popular são sistemas constitucionais mutuamente excludentes. Kramer define supremacia judicial sob um conceito de finalidade judicial. Ainda, algumas formas de finalidade judicial são essenciais para o estado de direito, que é necessário ao funcionamento da democracia. Por esta razão, tanto a supremacia judicial, quanto o constitucionalismo popular contribuem indispensavelmente para a política americana. Eles estão de fato dialeticamente interconectados e por muito tempo coexistiram" (POST, Robert C; SIEGEL, Reva B. Popular Constitutionalism, Departamentalism, and Judicial Supremacy. California Law Review, Berkeley, v. 92. p. 1029, 2004, tradução nossa. Disponível em: <http://digitalcommons.law.yale.edu/cgi/viewcontent.cgi?article=1177\&context=fss_ papers $>$. Acesso em: 18 de setembro de 2017).

73 POST, Robert C; SIEGEL, Reva B. Popular Constitutionalism, Departamentalism, and Judicial Supremacy. California Law Review, Berkeley, v. 92. p. 1030, 2004. Disponível em: < http://digitalcommons.law.yale.edu/cgi/ viewcontent.cgi?article=1177\&context=fss_papers $>$. Acesso em: 18 de setembro de 2017.

Vale aqui destacar a ressalva de que o modelo de reforma constitucional americano é bem mais árduo que o brasileiro, pois além de exigir o debate no Poder Legislativo, demanda ainda a ratificação de três quartos dos Estados. Fato que torna as mudanças constitucionais formais extremamente difíceis.
} 
expressão contra formas de censura. Ou seja, para que o povo possa se manifestar, é preciso que seus direitos constitucionais sejam salvaguardados. ${ }^{74}$

Para haver uma acomodação entre supremacia judicial e constitucionalismo popular, seria necessário um equilíbrio entre direito constitucional e Constituição. "A partir desta nomenclatura, 'direito constitucional' refletiria o julgamento e opiniões das cortes, enquanto que 'Constituição' expressaria as crenças fundamentais do 'We the people ${ }^{\prime \prime \prime 75}$. Permitir que o Direito Constitucional dite o que é Constituição é arriscado, podendo as crenças constitucionais da nação serem suplantadas pela estreita visão das Cortes e, ao mesmo tempo, permitir o mero julgamento político da Constituição é perigoso por colocar os direitos constitucionais e valores da democracia em situação de vulnerabilidade. $^{76}$

Quanto maior o direito constitucional, mais os atores não judiciários estão vinculados às visões das Cortes e menor o espaço para a criação política da Constituição. Por isto, Post e Siegel enfatizam a necessidade de um equilíbrio entre Constituição e Direito Constitucional para que Supremacia Judicial e Constitucionalismo Popular coexistam. ${ }^{77}$

Robert Post e Reva Siegel defendem o que denominaram de "Constitucionalismo democrático" o qual equilibra a participação dos representantes do povo e os próprios cidadãos e também das cortes na interpretação constitucional.

Diferentemente do constitucionalismo popular, o constitucionalismo democrático não procura tirar a Constituição das cortes. Constitucionalismo democrático reconhece a participação essencial da interpretação judicial dos direitos na Política americana. Diferentemente de um foco juricêntrico, o constitucionalismo democrático aprecia a essencial participação do engajamento público em guiar e legitimar as instituições e práticas da revisão judicial. ${ }^{78}$

\footnotetext{
${ }^{74}$ POST, Robert C; SIEGEL, Reva B. Popular Constitutionalism, Departamentalism, and Judicial Supremacy. California Law Review, Berkeley, v. 92. p. 1036, 2004. Disponível em: <http://digitalcommons.law.yale.edu/cgi/ viewcontent.cgi?article=1177\&context=fss_papers $>$. Acesso em: 18 de setembro de 2017.

75 POST, Robert C; SIEGEL, Reva B. Popular Constitutionalism, Departamentalism, and Judicial Supremacy. California Law Review, Berkeley, v. 92. p. 1038, 2004, tradução nossa. Disponível em: < http://digitalcommons. law.yale.edu/cgi/viewcontent.cgi?article=1177\&context=fss_papers>. Acesso em: 18 de setembro de 2017.

${ }^{76}$ POST, Robert C; SIEGEL, Reva B. Popular Constitutionalism, Departamentalism, and Judicial Supremacy. California Law Review, Berkeley, v. 92. p. 1038, 2004. Disponível em: < http://digitalcommons.law.yale.edu/cgi/ viewcontent.cgi?article=1177\&context=fss_papers $>$. Acesso em: 18 de setembro de 2017.

77 POST, Robert C; SIEGEL, Reva B. Popular Constitutionalism, Departamentalism, and Judicial Supremacy. California Law Review, Berkeley, v. 92. p. 1040, 2004. Disponível em: <http://digitalcommons.law.yale.edu/cgi/ viewcontent.cgi?article=1177\&context=fss_papers $>$. Acesso em: 18 de setembro de 2017 .

${ }^{78}$ POST, Robert C; SIEGEL, Reva B. Roe Rage: Democratic Constitutionalism and Backlash. Harv. Civil Rights Civil Liberty Law Review., Cambridge, v. 42. p. 379, 2007, tradução nossa e grifos nossos.
} 
Os dois autores interpretam o fenômeno do backlash ${ }^{79}$ como algo positivo. Segundo eles, o backlash é uma forma de contestação das decisões judiciais e tentativa de influenciar a interpretação no direito constitucional. ${ }^{80}$

Alguns autores como Roberto Niembro, Ana Micaela Alterío e Lee Strang classificam o constitucionalismo democrático de Post e Siegel como uma espécie de constitucionalismo popular já que confere grande participação ao povo e aos movimentos sociais ${ }^{81}$. Não concordamos com esta concepção. Embora possua traços em comum com o constitucionalismo popular, o constitucionalismo democrático é modelo próprio que se interpõe entre o constitucionalismo popular e o constitucionalismo mais ortodoxo, em uma espécie de conciliação. Alterío, por exemplo, reconhece que o modelo proposto por Post e Siegel apresenta compatibilidade entre engajamento popular e supremacia judicial $^{82}$. O principal alvo do constitucionalismo popular é a supremacia judicial que de certa forma é defendida por Post e Siegel e, portanto, se difere do constitucionalismo popular embora, como enfatizado anteriormente, guarde pontos em comum.

Além da questão contramajoritária e dos direitos individuais, outra crítica está no excesso de confiança nos agentes eleitos. Chemerinsky afirma que os constitucionalistas populares apresentam uma fé injustificada nos ramos de poder eleitos de que estes conseguem cumprir a Constituição adequadamente ${ }^{83}$. Interessante, que como já adiantado, em outro tópico, Richard Parker problematiza uma questão de representação e distanciamento do eleitorado sem, no entanto, desenvolver. Durante seu artigo, Parker realiza uma crítica da revisão judicial por, supostamente, ser mais distanciado do "povo comum", contudo, ele próprio admite que o mesmo ocorre com a política ordinária que, em tese, deve ainda mais satisfação do povo comum, que conferiu seus

\footnotetext{
${ }^{79}$ Os próprios autores definem backlash como sendo "forças contrárias desencadeadas para evitar mudanças no status quo" (POST, Robert C; SIEGEL, Reva B. Roe Rage: Democratic Constitutionalism and Backlash. Harv. Civil Rights - Civil Liberty Law Review., v. 42. p. 389, 2007.).

${ }^{80}$ POST, Robert C; SIEGEL, Reva B. Roe Rage: Democratic Constitutionalism and Backlash. Harv. Civil Rights Civil Liberty Law Review., Cambridge, v. 42. p. 383, 2007.

${ }^{81}$ Cf. NIEMBRO, Roberto. Uma mirada al constitucionalismo popular. Isonomía, Ciudad de México, n. 38. p. 203-?, abr. 2013; ALTERÍO, Ana Micaela. Corrientes del constitucionalismo contemporáneo a debate. Anuario de Filosofia y Teoria del Derecho, Ciudad de México, n. 8, jan.-dez. p. 227-306, 2014. Disponível em: <http:// www.scielo.org.mx/pdf/is/n38/n38a7.pdf>. Acesso em: 18 de setembro de 2017.; STRANG, Lee J. Originalism as Popular Constitutionalism?: Theoretical Possibilities and Practical Differences. Notre Dame Law Review, Notre Dame, v. 87 p. 253-292, 2013. Disponível em: <http://scholarship.law.nd.edu/ndlr/vol87/iss1/5>. Acesso em: 18 de setembro de 2017. p. 256.

82 “Desde allí, Post y Siegel propician un diálogo constitucional inclusivo, especialmente sensible a los movimientos sociales, donde el pueblo debe retener la última palabra sobre el significado de la constitución, pero compatible con la idea de supremacía judicial" (ALTERÍO, Ana Micaela. Corrientes del constitucionalismo contemporáneo a debate. Anuario de Filosofia y Teoria del Derecho, Ciudad de México, n. 8, jan.-dez. p. 227-306, 2014. Disponível em: <http://www.scielo.org.mx/pdf/is/n38/n38a7.pdf>. Acesso em: 18 de setembro de 2017. p. 268).

${ }^{83}$ CHEMERINSKY, Erwin. In defense of judicial review: The perils of popular constitutionalism. University of Illinois Law Review, Champaign, n. 3. p. 673-690, 2004. Disponível em: <http://scholarship.law.duke.edu/cgi/ viewcontent.cgi?article=2144\&context=faculty_scholarship >. Acesso em: 29 de julho de 2017. p. 679.
} 
mandatos a partir do voto. O Direito Constitucional e o Judiciário se tornam alvo das críticas, no entanto, ao Parlamento são endereçadas poucas palavras.

Outra questão levantada por Chemerinsky é que não existe apenas o controle de constitucionalidade dos atos produzidos por agentes democraticamente eleitos, mas também de atos produzidos por outros agentes não eleitos, como agentes de polícia e agências reguladoras. ${ }^{84}$

Diferentemente dos autores anteriormente mencionados, Jonathan Siegel realiza uma crítica ao constitucionalismo popular partindo de uma perspectiva institucional do problema. Para tal, o autor realiza uma exposição comparativa entre o judicial review com o processo eleitoral e os processos legislativos. Assim, procura demonstrar que o Poder Judiciário possui características peculiares que o colocam em vantagem para a efetividade do direito constitucional e garantia dos direitos fundamentais, sobretudo dos direitos individuais. ${ }^{85}$

Segundo Jonathan Siegel, algumas pessoas acreditam que o processo eleitoral poderia ser um mecanismo de efetivar a Constituição contra violações. Esta ideia viria da seguinte lógica: se determinado político viola a Constituição, a população não votará mais nele. ${ }^{86}$

Contudo, o autor apresenta argumentos demonstrando que o processo eleitoral não é apropriado para isso. Em primeiro lugar, porque não há correlação necessária entre a violação constitucional e a represália do eleitorado. Isto porque o processo eleitoral não é focado em uma determinada matéria, muito menos constitucional. A ausência de votos de um político na próxima eleição pode ser confundida com vários outros problemas, como questões políticas, econômicas, morais, etc. Além disso, as eleições não apresentam oportunidades claras para expressar visões sobre aspectos constitucionais. Diferentemente, o processo judicial é focado em um caso específico, sendo em matéria constitucional, a violação da Constituição. ${ }^{87}$

Outra diferença entre o processo eleitoral e o judicial é que o segundo é transparente, enquanto o segundo é inescrutável ${ }^{88}$. Obviamente, o processo judicial não é

${ }^{84}$ CHEMERINSKY, Erwin. In defense of judicial review: The perils of popular constitutionalism. University of Illinois Law Review, Champaign, n. 3. p. 673-690, 2004. Disponível em: <http://scholarship.law.duke.edu/cgi/ viewcontent.cgi?article=2144\&context=faculty_scholarship $>$. Acesso em: 29 de julho de 2017. p. 682.

${ }^{85} \mathrm{Cf}$. SIEGEL, Jonathan R. The institutional Case for Judicial Review. Iowa Law Review, lowa City, v. 97. p. 11471199, 2012. Disponível em: < https://papers.ssrn.com/sol3/papers.cfm?abstract_id=2079129>. Aceso em 18 de setembro de 2017.

${ }^{86}$ SIEGEL, Jonathan R. The institutional Case for Judicial Review. lowa Law Review, lowa City, v. 97. p. 1165, 2012. Disponível em: < https://papers.ssrn.com/sol3/papers.cfm?abstract_id=2079129>. Aceso em 18 de setembro de 2017.

${ }^{87}$ SIEGEL, Jonathan R. The institutional Case for Judicial Review. lowa Law Review, lowa City, v. 97. p. 11681169, 2012. Disponível em: < https://papers.ssrn.com/sol3/papers.cfm?abstract_id=2079129>. Aceso em 18 de setembro de 2017.

${ }^{88}$ SIEGEL, Jonathan R. The institutional Case for Judicial Review. lowa Law Review, lowa City, v. 97. p. 1171, 2012. Disponível em: <https://papers.ssrn.com/sol3/papers.cfm?abstract_id=2079129>. Aceso em 18 de setembro de 2017. 
totalmente transparente, isto porque nem sempre os juízes são claros em apresentar as razões que os levam a tomar suas decisões. No entanto, o processo judicial é muito mais transparente que o processo eleitoral. ${ }^{89}$

Por fim, outra vantagem importante do judicial review é que este é individual, enquanto o processo eleitoral depende de uma coletividade, ou seja, o processo eleitoral ignora as violações constitucionais vivenciadas por indivíduos isolados. $\mathrm{O}$ autor, entretanto, reconhece que os constitucionalistas populares não esperam que a Constituição seja preservada apenas através pelo processo eleitoral, mas por todo o processo político, incluindo a legislatura, a imprensa, o direito de petição, interesses de grupos, etc..$^{90}$

Por isto, o mesmo comparativo que Jonathan Siegel faz do judicial review com o processo eleitoral, ele faz do judicial review para com os processos legislativos. Afirma o autor que embora os processos legislativos sejam capazes de promover debates constitucionais, não existe qualquer garantia de que estes serão realizados. Os Cidadãos não teriam qualquer poder para fazer com que o corpo legislativo aprecie uma questão constitucional separadamente. Sendo assim, o autor demonstra que embora o processo legislativo tenha uma possibilidade muito melhor de levar em conta questões constitucionais do que o processo eleitoral, ainda fica atrás do processo judicial. ${ }^{91}$

A mesma lógica é aplicada pelo autor no quesito transparência. Diferentemente do processo eleitoral, no processo legislativo é possível que os parlamentares exponham suas razões para a tomada de determinadas decisões. No entanto, não há qualquer garantia de que haverá fundamentação das decisões. Resumindo, a principal diferença é que, no processo legislativo, a atuação é discricionária, enquanto no processo judicial é mandatória. ${ }^{92}$

Sintetizando a sua crítica, o autor explica: "A combinação da natureza discricionária do processo legislativo com a não focada e inescrutável natureza do processo eleitoral é um obstáculo duplo que torna o processo político como um todo um veículo pobre de efetivação dos direitos constitucionais" ${ }^{\prime \prime 3}$. Referindo-se, evidentemente, aos direitos individuais.

${ }^{89}$ SIEGEL, Jonathan R. The institutional Case for Judicial Review. lowa Law Review, lowa City, v. 97. p. 1173$1174,2012$.

${ }^{90}$ Outras vantagens do judicial review em relação ao processo eleitoral apresentadas pelo autor são: que este é baseado em um sistema de precedentes e, ainda, em direitos; enquanto o processo eleitoral não possui qualquer sistema de precedentes e tem um caráter meramente majoritário (SIEGEL, Jonathan R. The institutional Case for Judicial Review. Iowa Law Review, lowa City, v. 97. p. 1177, 2012).

${ }^{91}$ SIEGEL, Jonathan R. The institutional Case for Judicial Review. lowa Law Review, lowa City, v. 97. p. 11781180, 2012. Disponível em: < https://papers.ssrn.com/sol3/papers.cfm?abstract_id=2079129>. Aceso em 18 de setembro de 2017.

92 SIEGEL, Jonathan R. The institutional Case for Judicial Review. lowa Law Review, lowa City, v. 97. p. 11811182, 2012. Disponível em: < https://papers.ssrn.com/sol3/papers.cfm?abstract_id=2079129>. Aceso em 18 de setembro de 2017 .

${ }^{93}$ SIEGEL, Jonathan R. The institutional Case for Judicial Review. lowa Law Review, lowa City, v. 97. p. 1185, 2012. Disponível em: < https://papers.ssrn.com/sol3/papers.cfm?abstract_id=2079129>. Aceso em 18 de setembro de 2017. 


\section{CONSIDERAÇÕES FINAIS}

Os constitucionalistas populares defendem um modelo em que o Poder Judiciário não tenha protagonismo na interpretação constitucional, transferindo este protagonismo ao povo, o verdadeiro detentor da Constituição. Alguns autores, como Larry Kramer e Richard Parker partem, em alguns momentos, para discursos bastante críticos dos que defendem um modelo de supremacia judicial, chamando-os de aristocratas.

No entanto, ao fazer isto, os constitucionalistas populares ignoram duas questões importantes. A primeira é a possibilidade de uma posição mais conciliatória, que defenda o controle de constitucionalidade no sentido forte e, ainda, incentive o engajamento popular para que este se posicione a respeito das decisões em sede de revisão judicial. Este posicionamento mais moderado pode ser visto no constitucionalismo democrático de Robert Post e Reva Siegel.

Outro problema do constitucionalismo popular é subestimar o problema do abuso do governo da maioria, que pode levar a opressão de minorias. Importante ter-se em mente que a ideia de um problema contramajoritário não significa que as maiorias irão atormentar as minorias recorrentemente. Apesar da função contramajoritária das cortes, espera-se que esta função tenha de ser exercida muito raramente.

Por fim, a crítica de Jonathan Siegel, em uma perspectiva institucional demonstra as vantagens que a revisão judicial possui em comparação com outros processos políticos para preservar os direitos e liberdades constitucionais. A proposta dada pelo autor de conferir aos ministros da Suprema Corte (ou do Supremo Tribunal Federal, no Brasil) um mandato submetido a um termo é interessante para que os representantes do povo possam substituir ministros que não estejam realizando uma interpretação condizente com os ideários do povo ou reconduzi-los se estiverem.

A principal contribuição do constitucionalismo popular é atacar uma visão juricêntrica, iludida com personalidades vestidas em togas e com uma visão de que a Constituição deve ser interpretada por semideuses em um Monte Olimpo. É preciso, de fato, trazer o povo para o debate constitucional e empoderá-lo para que possa participar das transformações constitucionais. Os juízes constitucionais devem ter sempre em mente que servem ao povo, como nas palavras de Larry Kramer: "a Suprema Corte é nosso servo e não nosso mestre" 94 . Ou como, na Constituição Brasileira: "todo poder emana do povo"95, "todo poder" inclui o Judiciário.

\footnotetext{
${ }^{94}$ KRAMER, Larry. The people themselves. Kindle Edition. Oxford: Oxford University Press, 2004. p. 248, tradução nossa.

${ }^{95}$ BRASIL. Constituição da República Federativa do Brasil de 1988. Brasília, DF, 5 out. 1988. Disponível em: <http://www.planalto.gov.br/ccivil_03/constituicao/constituicao.htm>. Acesso em: 20 de setembro de 2017.
} 


\section{REFERÊNCIAS}

ALTERÍO, Ana Micaela. Corrientes del constitucionalismo contemporáneo a debate. Anuario de Filosofia y Teoria del Derecho, Ciudad de México, n. 8, jan.-dez. p. 227-306, 2014. Disponível em: <http://www.scielo.org.mx/pdf/is/n38/n38a7.pdf>. Acesso em: 18 de setembro de 2017.

BANCROFT, George. History of the Constitution of the United States. New York: D. Appleton and Company, 1882. Disponível em: <https://archive.org/details/historyofformati01 banc $>$. Acesso em: 21 de julho de 2017.

BEARD, Charles A. A Suprema Côrte e a Constituição. Tradução de Paulo Moreira da Silva. Rio de Janeiro: Forense, 1965.

BICKEL, Alexander. The Least Dangerous Branch. 2. ed. New Haven: Yale University Press, 1986.

CHEMERINSKY, Erwin. In defense of judicial review: The perils of popular constitutionalism. University of Illinois Law Review, Champaign, n. 3, p. 673-690, 2004. Disponível em: <http://scholarship.law.duke.edu/cgi/viewcontent.cgi?article=2144\&context=faculty_scholarship $>$. Acesso em: 29 de julho de 2017.

FRIEDMAN, Barry. Mediated Popular Constitutionalism. Michigan Law Review, Ann Arbor, v. 101, p. 2595-2632, 2004. Disponível em: <https://www.researchgate.net/profile/Barry_Friedman2/publication/228186449_Mediated_Popular_Constitutionalism/links/0deec52568b6842140000000. pdf $>$. Acesso em: 29 de julho de 2017.

JÁCOME, Jorge González. ¿El poder para la gente? Una introducción a los debates sobre el Constitucionalismo popular.... In: CHEMERINSKY, Erwin; PARKER, Richard D.; JÁCOME, Jorge González. Constitucionalismo Popular. Bogotá: Siglo del Hombre Editores, 2011.

KNOWLES, Helen J.; TOIA, Julianne A. Defining "Popular Constitutionalism": The Kramer Versus Kramer Problem. Southern University Law Review, Baton Rouge, 9 abr. 2014. Disponível em: <https://ssrn.com/abstract=2395465>. Acesso em: 17 de setembro de 2017.

KRAMER, Larry. "Democracia Deliberativa e Constitucionalismo Popular: James Madison e o "Interesse do Homem". In: BIGONHA, Antonio Carlos; MOREIRA, Luiz (org.). Limites do Controle de Constitucionalidade. Rio de Janeiro: Lumen Juris, 2009. Tradução de Adauto Villela.

KRAMER, Larry. Popular Constitutionalism, Circa 2004. California Law Review, Berkeley, v. 92, p. 959-1012, jul. 2004.

KRAMER, Larry. The people themselves. Kindle Edition. Oxford: Oxford University Press, 2004.

MADISON, James. Federalist No. 10 - The Same Subject Continued: The Union as a Safeguard Against Domestic Faction and Insurrection. In: The Federalist Papers. New York Packet, 23 nov. 1787. Disponível em: <https://www.congress.gov/resources/display/content/The+Federalist+Papers\#TheFederalistPapers-10>. Acesso em: 29 de julho de 2017. 
MADISON, James. Who Are the Best Keepers of the People's Liberties?.National Gazette, 22 dec. 1792. Disponível em: <http://www.constitution.org/jm/17921222_keepers.htm>. Acesso em: 23 de julho de 2017.

MEIGS, William M. The Relation of the Judiciary to the Constitution. New York: The Neale Publishing Company Disponível em: <https://archive.org/details/relationjudicia00meiggoog >. Acesso em: 21 de julho de 2017.

NIEMBRO, Roberto. Uma mirada al constitucionalismo popular. Isonomía, Ciudad de México, n. 38, p. 203-?, abr. 2013.

PARKER, Richard Davies. "Here, the people rule”: a constitutionalist populist manifesto. Valparaíso University Law Review, Valparaíso, v. 27, n. 3, p. 531-584, 1993. Disponível em: <https://dash. harvard.edu/handle/1/12967873>. Acesso em: 23 de julho de 2017.

POST, Robert C; SIEGEL, Reva B. Popular Constitutionalism, Departamentalism, and Judicial Supremacy. California Law Review, Berkeley, v. 92, p. 1027-1044, 2004.

POST, Robert C; SIEGEL, Reva B. Roe Rage: Democratic Constitutionalism and Backlash. Harv. Civil Rights - Civil Liberty Law Review., Cambridge, v. 42, p. 373-433, 2007.

POZEN, David E. Judicial Elections as Popular Constitutionalism. Columbia Law Review, New York, v. 110, n. 8, p. 2047-2134, dec. 2010.

PROFESOR Jeremy Waldron de la Universidad de Nueva York, en la Corte Constitucional, seminario sobre control de constitucionalidad y política. Publicado por: Corte Constitucional. Bogotá: Tribunal Constitucional da Colômbia, 2017. Youtube (1h40min). Disponível em: <https://www. youtube.com/watch?v=8I_WGqY3qMA>. Acesso em: 23 de setembro de 2017

RODRIGUES, Lêda Boechat. A Corte Suprema e o Direito Constitucional Americano. 2. ed. Rio de Janeiro: Civilização Brasileira, 1992.

SIEGEL, Jonathan R. The institutional Case for Judicial Review. lowa Law Review, lowa City, v. 97, p. 1147-1199, 2012. Disponível em: <https://papers.ssrn.com/sol3/papers.cfm?abstract_ $\mathrm{id}=2079129$. . Aceso em 18 de setembro de 2017.

STRANG, Lee J. Originalism as Popular Constitutionalism?: Theoretical Possibilities and Practical Differences. Notre Dame Law Review, Notre Dame, v. 87 p. 253-292, 2013. Disponível em: <http://scholarship.law.nd.edu/ndlr/vol87/iss1/5>. Acesso em: 18 de setembro de 2017.

THAYER, James Bradley. The Origin and Scope of The American Doctrine of Constitutional Law. Boston: Little, Brown, and Company, 1893. Disponível em: <https://archive.org/details/originandscopea00thaygoog>. Acesso em: 29 de julho de 2017.

TOCQUEVILLE, Alexis de. A Democracia na América. São Paulo: Folha de São Paulo, 2010.

TUSHNET, Mark. Abolishing Judicial Review. Constitutional Commentary, Minneapolis, v. 27, p. 581-589,2011.Disponívelem:<https://conservancy.umn.edu/bitstream/handle/11299/163457/8- 
Tushnet-273-AbolishingJudicialReview.pdf?sequence=1>. Acesso em: 18 de setembro de 2017. TUSHNET, Mark. Popular Constitutionalism As Political Law. Chicago-Kent Law Review, Chicago, v. 81, p. 991-1006, 2006.

TUSHNET, Mark. Taking the Constitution away from the Courts. Kindle Edition. Princeton: Princeton University Press, 1999.

UNITED STATES OF AMERICA. Supreme Court of United States. Brown v. Allen. 344 U.S. 443 (1953). Disponível em: <https://supreme.justia.com/cases/federal/us/344/443/case.html>. Acesso em 29 de julho de 2017.

UNITED STATES OF AMERICA. Supreme Court of United States. Hollingsworth v. Perry. Disponível em: <https://www.supremecourt.gov/opinions/12pdf/12-144_8ok0.pdf>. Acesso em: 28 de julho de 2017.

UNITED STATES OF AMERICA. Supreme Court of United States. Marbury V. Madison. Disponível em: <https://supreme.justia.com/cases/federal/us/5/137/case.html>. Acesso em: 22 de julho de 2017.

UNITED STATES OF AMERICA. Supreme Court of United States. Lochner v. New York. Disponível em: <https://supreme.justia.com/cases/federal/us/198/45/case.html>. Acesso em: 22 de julho de 2017.

WALDRON, Jeremy. The core of the case against judicial review. The Yale Law Review, New Haven, v. 115, p. 1346-1406, 2006.

WESTIN, Alan F. Introdução. In: BEARD, Charles A. A Suprema Côrte e a Constituição. Trad. Paulo Moreira da Silva. Rio de Janeiro: Forense, 1965. 